\title{
A ANTROPOLOGIA DE AGOSTINHO DE HIPONA, FORTITUDO CORPORIS NA HIERARQUIA DOS BENS CRIADOS
}

Nilo César B Silva

UFS

Resumo: O estudo pretende investigar na obra de Agostinho de Hipona as bases para uma antropologia filosófica. O problema antropológico formulado por Agostinho do composto corpo/alma, como partes integrantes da condição humana, se destaca com algumas oscilações na evolução de seus escritos. Antes de tudo, Agostinho assume uma posição propensa à negatividade do corpo e seu lugar na escala valorativa dos bens criados ao desconfiar dos estímulos e solicitações que o corpo recebe da exterioridade dos sentidos, que poderão desviar o homem no itinerário da sabedoria e da verdade. Por conseguinte, na esteira da literatura paulina, o hiponense assume a positividade do corpo como morada da alma, ocupando, assim, um lugar de destaque e valor estimado na ordem das criaturas. Em De quantitate animae (obra cuja data de composição se situa entre 387 e 388), Agostinho confirma essa noção de alma como substância dotada de razão e, portanto, apta para governar o corpo em vista de sua grandeza. Uma vez que esta doutrina considera a alma uma realidade espiritual e superior no homem, o corpo deve colocar-se numa posição de subordinação.

Palavras-chaves: Agostinho de Hipona; antropologia; corporeidade; alma.

\begin{abstract}
The study aim to investigate the work of Augustine of Hippo the foundation for a philosophical anthropology. The anthropological problem formulated by Augustine compound body/soul, as an integral part of the human condition stands out with some fluctuations in the evolution of his writings. First of all, Augustine assumes a prone position on the negativity of the body and its place in the evaluative scale of the assets created to distrust the stimuli and requests that the body receives the externality of the senses that can divert the man on the itinerary of wisdom and truth. Therefore, in the wake of the Pauline literature hiponense takes the body positivity as seat of the soul, thus occupying a prominent place and estimated in the order of creatures. De quantitate animae (work whose date of composition is between 387 and 388), Augustine confirms this notion of soul as substance endowed with reason and therefore properly able to rule the body because of its greatness.
\end{abstract}

Keywords: Augustine of Hippo; anthropology; corporeality; soul.

Grande abismo é o próprio homem, cujos cabelos tu, Senhor, tens contados e não se diminuem sem ti. E todavia, os seus cabelos são mais fáceis de contar que os afetos e as emoções do seu coração. Confissões, IV, 14, 22. 


\section{Introdução}

Quando pensamos em abordar a concepção do homem na filosofia medieval, imediatamente nos referimos à antropologia dos Padres da Igreja, representada por Tertuliano (220), Orígenes de Alexandria (184-254), Jerônimo (348-420), Gregório de Nissa (340), Ambrósio (340-397) e Agostinho de Hipona (354-430). Segundo o biógrafo Peter Brown, Agostinho ao nascer na cidade de Tagaste, ela já existia há quase 300 anos, portanto, considerada a vanglória que os romanos haviam espalhado por todo o norte da África, por meio do resplandecente conselho de Tagaste. Brown nos faz perceber detalhes importantes neste contexto. Com efeito, "ao pensar em Agostinho de Hipona, logo a nossa imaginação é dominada pelo selvático e ermo território africano, porém o filósofo cresceu e viveu na África de Cartago, na costa do mediterrâneo, a mais de trezentos quilômetros do mar e 610 metros acima dele, separado do mediterrâneo por grandes florestas de pinheiros e por vales altos, cobertos de milharais e olivais" (BROWN, 2008, p. 23-24). Agostinho era filho de pai pagão e mãe cristã, Mônica, que exerce um papel importante na vida de Agostinho, por meio dela recebeu sua primeira instrução escolar, embora de imediato não fosse batizado segundo o costume então muito difundido no catolicismo, o que lhe permitiu ainda jovem se agradar da doutrina maniqueísta.

$\mathrm{Na}$ juventude, Agostinho sentiu-se atraído pelo maniqueísmo onde nele se fez discípulo por algum tempo. A princípio, a doutrina de Mani parecia interessante aos olhos de Agostinho por apresentar dois elementos importantes; primeiro, despertava o apreço à sabedoria, pois apresentava-se com o nome de gnose ou ciência sendo capaz de responder sistematicamente as perguntas sobre a origem do universo e da alma humana, além de oferecer contundentes respostas ao problema da natureza do mal que assola a vida humana. O maniqueísmo também se apresentava na forma de gnosticismo cristão ou, melhor dizendo, muito semelhante à filosofia do cristianismo, no modo como abordava as questões desafiadoras da existência humana, a saber, a felicidade, a origem da vida e seu destino. Mas, a adesão que Agostinho faz ao maniqueísmo não perdura por muito tempo, logo que conhece o neoplatonismo torna-se pungente adversário de Mani e, por conseguinte, escreve vários Opúsculos refutando as teses maniqueístas.

De modo indubitável, a formação filosófica de Agostinho tem reflexos neoplatônicos, haja vista suas próprias declarações em suas Confissões. O Platonismo não foi apenas um ingrediente da evolução espiritual de Agostinho, culminante na sua conversão, mas foi também o instrumento e o tesouro dos conhecimentos mediante os quais e, exclusivamente por meio deles, o seu pensamento se formou. De fato, o pensamento de Agostinho é uma síntese da cultura helenística incorporada na latinidade, embora essa característica esteja 
pouco explicitada nos seus escritos e no decurso da história, até mesmo por questões doutrinárias da religião cristã da qual fazia parte. Há consenso entre diversos estudiosos de que a noção agostiniana de Deus traz referências analógicas ao uno neoplatônico, porque ambos representam o princípio do ser, do bem, do belo. No Platonicorum libri, Agostinho assimila, de certo modo, a concepção metafísica neoplatônica do ser. O neoplatonismo também forneceu recursos para a noção agostiniana de unidade e interioridade da alma, de fato, esse pensamento sustentou as grandes doutrinas místicas ao longo do medievo.

De outro modo é consensual afirmar que entre os muitos significados apresentados para o conceito de razão e de racionalidade no platonismo, nada foi mais destrutivo que a tentativa de opor sistematicamente razão e sensações, ou corpo/alma na tentativa de classificar os desejos no domínio da irracionalidade. Agostinho, embora nutrido de elementos platônicos, no que se refere ao primado axiológico da alma sobre o corpo, concomitantemente se afasta dessa perspectiva ao situar a questão da bondade do corpo na hierarquia dos bens criados, utilizando o termo bomo totus para designar a unidade do composto corpo/alma.

De acordo com Agostinho, toda a natureza mesmo que seja última e ínfima em comparação com o nada é digna de louvor, isso significa que os prazeres do corpo também são louváveis, mas podemos encontrar nessa multiplicidade de prazeres algo ignóbil, não porque o corpo seja mau por natureza, mas porque vergonhosamente se volta para o amor dos bens mais ínfimos, enquanto a nós seres humanos, imagem do criador,foi concedido aderir e fruir do mais elevado deles (De uera religione, 45,83) ${ }^{1}$. Agostinho, na esteira do neoplatonismo, procura enaltecer a natureza da alma humana que, apesar de quaisquer que sejam as suas imperfeições, não a fez nem fará perder sua condição incorpórea;isso significa dizer que, para o Hiponense a alma sempre será superior ao corpo, mesmo sendo modificada na sua integridade,por meio da corrupção do pecado,ela não perderá a sua marca de bondade(Cf. De libero arbitrio, III, 5,16)."Nas naturezas superiores é melhor um espírito racional mesmo corrompido por uma vontade má do que um irracional incorrupto. E,

${ }^{1}$ No que se refere às obras de Agostinho, usamos sempre que disponíveis edições bilingues portuguêsLatim. Nas universidades portuguesas está hoje disponível um conjunto de edições de obras de Agostinho que abrangem já algumas das principais obras deste autor. É o caso do Diálogo sobre Felicidade, do Diálogo sobre a Ordem, do Diálogo sobre o Livre arbítrio, das Confissões, de A Trindade, do pequeno opúsculo $A$ Natureza do bem e de $A$ verdadeira religião em um livro. Com exceção a obra, $A$ Cidade de Deus, em três volumes, na edição da Fundação Calouste Gulbenkian. Essa foi a edição de nossa referência que pela ausência do texto latino que a acompanhe, recorremos a outra edição para confrontarmos com o texto latino, isto é, a edição da Nuova Biblioteca Agostiniana - NBA. Cf. Sant'Agostino, Città di Dio «De civitate Dei», Nuova Biblioteca Agostiniana (NBA) - Opere di Sant'Agostino (ed. Latino-Italiana) - vol. V/1 (libri I -X); V/2 (libri XI - XVIII); V/3 (libri XIX - XXII) Roma, Città Nuova Editrice, 1978 - 1991 (Texto latino da Ed. Maurina confrontado com CSEL). 
qualquer espírito, mesmo corrompido, é melhor do que qualquer corpo incorrupto [...]. Por muito corrompido que seja um espírito, ele pode dar vida a um corpo,por isso, mesmo corrompido, ele é melhor do que um corpo incorrupto"(Cf. De natura boni, I, 5).

\section{A Fortitudo corporis et animae na doutrina agostiniana do homo totus}

«corpus animae cohaerere ut homo totus et plenus sit»

O problema antropológico formulado por Agostinho do composto corpo/alma, como parte integrante da condição humana se destaca com algumas oscilações na evolução de seus escritos. Antes de tudo, Agostinho assume uma posição propensa à negatividade do corpo e seu lugar na escala valorativa dos bens criados, ao desconfiar dos estímulos e solicitações que o corpo recebe da exterioridade dos sentidos que poderão desviar o homem no itinerário da verdade.Por conseguinte, na esteira de Paulo de Tarso,o hiponense assimila a positividade do corpo como morada da alma, o que deve ser cuidado e amado pelo valor que ocupa na ordem dos bens criados.

Em De quantitate animae (obra cuja data de composição se situa entre 387 e 388), Agostinho confirma a noção de alma como substância dotada de razão e, portanto, apta para governar o corpo em vista de sua grandeza (Cf. De Quantitate animae 13, 22) $)^{2}$. Uma vez que sua doutrina considera a alma uma realidade espiritual em que confere a dimensão superior do homem, o corpo deve colocar-se numa posição inferior na escala das naturezas criadas. Dessa forma, a união corpo e alma se apresenta como meramente acidental, mesmo assim, o corpo humano não se exclui de qualquer valor na ordem dos bens criados.

O problema filosófico descrito inicialmente por Agostinho na obra De quantitate animae (388) é axiológico e não ontológico, porque se refere ao lugar ou posição valorativa que o corpo e a alma ocupam como criaturas de Deus. De acordo com Agostinho, o erro dos platônicos consiste em buscar compreender o corpo como estorvo da alma por causa das paixões que a alma está forçada a suportar devido sua vinculação com o corpo. O De civitate Dei, (413-426) considerado texto importante na relação dos escritos tardios de Agostinho, os quais expressam a maturidade do filósofo, esboça nos livros IX e XIV uma teoria dos afetos na perspectiva avaliativa ético-moral da sexualidade humana,

2SAN AGUSTIN, De la cuantidad del alma/De Quantitate animae13, 22 in: Obras completas de san Agustín. $3^{\mathrm{a}}$ ed. Bilingue latim/espanhol. versión, introducciones y notas Trad. introd. y notas de Victorino Capánaga, et al.Madrid: La Editorial Catolica/BAC, 1963, p. 448. Toda referência a esta obra segue doravante esta edição da BAC. Nossa tradução, do castelhano. 
onde Agostinho assume posições bem mais moderadas para amenizar a conotação negativa dos afetos e da sexualidade humana na atividade corpo/alma. A sua crítica à metafísica platônica consiste em identificar o entrave negativo do valor do corpo na estrutura ontológica do ser humano, portanto, Agostinho exorta aos platônicos para que "deixem-se de apresentar o corpo humano como um castigo com que ameaça a alma, ou então não exaltem o culto desses deuses que nos exortam a fugir e a evitar com todas as nossas forças o corpo que eles nos deram, tanto uma coisa como a outra são totalmente falsas" (De civitate Dei, XII, 27).

Os neoplatônicos foram imprescindíveis na definição da natureza humana e da potencialização da alma, por seu turno, suas doutrinas registram que a alma se realiza a si mesma quando orienta a sua vida pelo divino, isto é, Plotino já afirmava que a alma é influenciada das características ontológicas pelas quais se orienta. Se ela direciona o seu olhar para as coisas inferiores e enxerga a felicidade nos bens materiais, sensíveis, mutáveis e transitórios, deve, portanto, se dispersar na multiplicidade e torna-se, ela mesma, instável, inquieta e dispersa. $\mathrm{Se}$, ao contrário, busca as realidades inteligíveis, almeja o absoluto, de fato, permanece quase sempre estável, ordenada, ou seja, ela própria adquire estabilidade, unidade e inteireza.

Os diálogos filosóficos de Agostinho escritos no período do retiro de Cassicíaco (386-396) de modo geral pretendem apresentar uma ontologia unitiva da relação corpo/alma, obtendo como vértice desta ontologia a potencialidade da alma no itinerário a Deus. Nas obras, De libero arbitrio (390) e De quantitate animae (388), Agostinho procura demonstrar os argumentos sobre a natureza da alma como substância que dá vida, atribuindo valor maior do que aquela que a recebe, pois, um corpo, seja ele qual for nutrido de paixões não poderia vencer um espírito dotado de virtudes, além disso, toda a alma mesmo a mais viciosa é melhor do que o corpo.

Pensas que a paixão é mais poderosa do que a mens, à qual reconhecemos ter sido confiado, por lei eterna, o domínio sobre as paixões? Eu, de facto, de modo algum penso que assim seja. E não seria absolutamente ordenado que as realidades mais fracas dominassem as mais fortes. Por isso, julgo que é necessário que a mente seja mais poderosa do que o desejo desenfreado, precisamente porque é reto e justo que ela a domine. [...] E, então? Porventura duvidaremos que toda a virtude se deve antepor a todo vício, de tal modo que, quanto melhor e mais sublime for a virtude, tanto mais firme e invencível ela se torna? [...] nenhum espírito vicioso supera, portanto, um espírito armado de virtude (De libero arbitrio I, 10, 20). 
O corpo na escala da criação deve ser considerado uma natureza inferior em relação à potência da mente, nesta se encontra a força que orienta o homem para a unidade (De ordine, II,11, 30). Em analogia a disfuncionalidade de um organismo, Agostinho caracteriza a desordem da mente em seu desgoverno sobre a paixão corporal. De fato, o domínio sobre a paixão corporal se obtém da mente orientada pela vontade, revestida de virtude, por sua vez, mantém o vigor para que o governo da libido corporal não se sobreponha e certamente se solidifique em necessidade para quem não resiste a ele, e por sua vez não lute contra ele. Como exemplo identificamos a lei do pecado que se exerce na tirania do hábito, pelo qual a alma, mesmo contrafeita, é arrastada e presa, e merecidamente, porque, querendo ou não, se deixa cair voluntariamente na maldade.

Contudo, apesar das mazelas provocadas por meio da dispersão dos sentidos corporais, não podemos negar a bondade do corpo na ordem da criação, mesmo que o pecado original possa lhe descaracterizar. Agostinho em seus primeiros escritos, em De Ordine (386), justifica a dimensão valorativa, positiva do corpo humano, antes como realidade animal - corpórea, porém dotada de racionalidade e mortalidade (Cf. De ordine, II,11, 31), por estas razões, o corpo não pode ser dissociado das demais realidades humanas. $\mathrm{Na}$ atividade corpórea a alma sente as dores e os prazeres, conhece as realidades sensíveis, faz intervenções no mundo e opera por meio dele. Assim, baseado na convicção de que a dimensão corpórea do homem, enquanto postulado filosófico foi a pedra angular rejeitada pelos clássicos no seu edifício conceitual, Agostinho, diferentemente, formula sistematicamente um problema decisivo para a filosofia de sua época, sobre a positividade do corpo e sua posição na ordem dos bens criados. Isto é, propõe uma abordagem filosófica do corpo que the confira significação e valor na fórmula do bomo totus.

O corpo mesmo situado como um bem ínfimo, sem vida própria, mas que recebe sua vida da alma, encontra-se, não obstante, como um bem louvável ao Criador.

Contudo, é necessário que recordes que seja os grandes bens, que seja os mais pequenos, só podem existir porque provêm Daquele de quem derivam todos os bens, quer dizer, de Deus. Foi disto que nos convenceu a discussão anterior, à qual tanta vez prestaste assentimento com alegria. Portanto, as virtudes, pelas quais se vive com retidão, são grandes bens. E todo o tipo de beleza corporal, sem a qual se pode viver com retidão, é um bem ínfimo. (...) A sua bondade deve louvar-se mais nos grandes bens do que nos médios, e mais nos médios do que nos ínfimos. Mas mais deve ser louvada por todos eles do que se os não tivessem dado todos (De libero arbitrio, II, 19, 50). 
A antropologia agostiniana esboçada na segunda parte do De libero arbitrio temcorrelação precisa com os argumentos da metafísica da criação exposta em partes do De vera religione, em ambos escritos o autor procura explicar que a bondade ou malícia do corpo dependem do bom ou mau uso que fazemos dele $^{3}$. Conforme os argumentos usados por Agostinho, a maior ou menor dignidade do corpo, depende do uso que fazemos de seus membros, pois quando não usamos as coisas com retidão, quase sempre fazemos mau uso delas.Todavia, a maior corrupção da alma racional está na vontade de fazer aquilo que a suma Verdade nos impede. Agostinho define toda pessoa humana corpo/alma como um bem, por pouco que a alma amante de Deus a domine, obviamente o corpo é um bem inferior, mas belo em seu gênero por levar impressa a forma e a espécie" (De uera religione,20,40). De tal modo que a negatividade não se encontra nos bens em si mesmo, mas na má vontade do homem ao faz mal uso desses bens. A bondade ou malícia depende do uso que fazemos das coisas criadas, quando usamos com sabedoria e retidão os membros do corpo, sempre prestamos um louvor ao criador.

Portanto, se entre os bens do corpo encontramos alguns de
que o ser humano pode não usar com retidão, nem por isso
dizemos que eles não lhe deviam ter sido dados, pois
reconhecemos que são bens: por que razão nos havia de
admirar o fato de existirem igualmente no espírito alguns bens
de que também podemos não usar com retidão, mas, porque
são bens, não nos poderiam ter sido dados a não ser por Aquele
de quem derivam todos os bens? (De libero arbitrio, II, 18,48)

De todo modo, percebemos em Agostinho a preocupação em livrar o corpo de tantas penas impostas pela tradição platônica, visto que o cerne do problema humano e seu agir não se encontram na malícia dos sentidos do corpo, mas na alma propulsora da vontade. De fato, sofremos tantas coisas que não seríamos forçados a sofrer se a nossa natureza obedecesse à integridade da vontade, de todas as formas e em todas as suas partes (Cf. De civitate Dei, XIV, 15). Estamos plenamente embaraçados quando as dores resultantes das paixões que se dizem da carne são elas da alma que as sente na carne; e procedem da carne, pois no próprio prazer corporal, encontramos como aprender a desprezálo, não pela malícia do corpo, mas porque é vergonhoso revolver-se no apego

${ }^{3} 0$ valor e significado dado a condição humana e sua posição na hierarquia dos bens criados,lê-se nas obras de Agostinho de maneira bem mais ampla nos seguintes livros e parágrafos do De libero arbitrio, II, XVII, 46; XVIII, 47, 48, 49; XIX, 50, 51, 52, 53; XX, 54, pp.229-245;Aponta-se também registros em De vera religione nos parágrafos, 18,$35 ; 18,36 ; 20,38$. O principal argumento de Agostinho em De libero arbitrio, II, 17,46, consiste em afirmar que há no homem a existência de três realidades esse, uiuere e intelligere, tais realidades conferem a dimensão de excelência humana.Com efeito, o homo totus, corpo e alma toda natureza criada toma sua forma da forma imutável sem a qual dada a sua contingência não teriam ser. 
aos últimos bens, quando nos é permitido apegar-nos ao bem supremo, sempiterno e dele fruir (Cf. De uera religione, 45, 83).

Com efeito, nada pode ser considerado inútil na obra da criação divina, porque tudo na natureza proclama o louvor ao seu Criador e a própria beleza nos evoca ao conhecimento da verdade. Todas as naturezas, pelo simples fato de existirem, têm a sua medida e forma e certa harmonia, isto é, ordem consigo mesmas, e, portanto, são boas (Cf. De civitate Dei,XII, 5). Desse modo, devemos amar a beleza do corpo, porque o amor ao próprio corpo deve ser cultivado pelo ser humano positivamente, com medida, forma, ordem e seu devido lugar na escala axiológica dos bens criados. Quando se ama de forma desordenada com o amor desmedido ao bem ínfimo em detrimento ao bem supremo nos distanciamos do ser. Na verdade, o amor à beleza do corpo, bem ínfimo e carnal poderá ser mal quando esse amor a ele se antepõe ao amor a Deus:

Assim como a beleza do corpo, sem dúvida, obra de Deus, mas
bem ínfimo, carnal e temporal, é mal-amada quando Deus,
bem eterno, interior e sempiterno é posto em segundo plano e
tal como, abandonada a justiça, o ouro é amado pelo avarento,
não por falta do ouro mas do homem, - assim é também em
relação a toda criatura: por muito boa que seja, ela pode ser
amada com um amor bom ou mal, bom se a ordem é
salvaguardada, mal se é violada (De civitate Dei, XV, 22, p. 1397-
1398).

O fato é que o corpo mesmo sendo distinto da alma em condições axiológicas e mutabilidade contingente não deve ser o único culpado pela origem da desordem, visto que a precariedade da natureza humana vive sempre na extremidade do confronto consigo mesma ou com as partes que a compõe, isto é, o corpo, alma, espírito e vontade, há, portanto, nessa extremidade uma força que perpassa todas as fronteiras da miséria humana e o transpõe em direção ao ser. Esta potência da alma que foi amplamente reforçada na filosofia de Agostinho chama-se mens. Agostinho atribui a mente a capacidade máxima da alma no seu itinerário a Deus, não obstante, "a mente não pode ser disposta das alturas onde domina, e da reta ordem, por nenhuma outra realidade, a não ser pela vontade" (De libero arbitrio, I, 16, 34). O governo da mente é revigorado pelo movimento da vontade que, pela sua força, poderá frear as paixões desmedidas. $\mathrm{Na}$ vontade com o auxílio da graça divina se encontra toda a potencialidade para tomar posse da beatitude.

Creio que recordas, portanto, que na primeira discussão ficou suficientemente patente que nenhuma realidade torna a mente serva da paixão, a não ser a própria vontade. $\mathrm{Na}$ verdade, a mente não pode ser forçada a essa desonra nem por uma realidade superior, nem por igual a ela, porque isso seria injusto. Também não pode ser forçada por uma realidade 
inferior, porque esta não tem poder para fazê-lo. Resta, portanto, que seja próprio dela este movimento pelo qual a mente converte a vontade da fruição do Criador para a fruição das criaturas (De Libero arbitrio, III, 1, 2 p. 253).

\section{A noção de homo totus, corpo alma e espírito.}

Corpo, alma e espírito constituem a unidade substancial do homo totus. Entrementes não se deve entender a "unidade corpo e alma" no sentido radical do termo como se fosse uma única natureza, mas no sentido de que nessa composição obtemos a ideia constitutiva da pessoa humana. Essa junção pode ser considerada ontológica, ou seja, está na natureza da alma unir-se com o corpo, assim como na natureza do corpo unir-se com a alma, pois foram assim ontologicamente designados pelo Criador para viver em unidade. Tal que a reunião alma e corpo definem a essência metafísica de pessoa humana, visto que não é possível obter na doutrina agostiniana nenhuma prova da união acidental entre corpo e alma, assim como para o platonismo que em parte compreendia o corpo como punição para alma. Agostinho afirma que por testemunho da nossa natureza íntegra o corpo está unido à alma para que o homem seja inteiro e completo, "corpus animae cohaerere ut homo totus et plenus sit" (De Anima et eius origine I, 17, 28).

Com Agostinho o corpo adquiriu radicalmente novo significado para a filosofia, não apenas na fórmula da metáfora cristã sob o signo de que o corpo não deverá ser apenas a morada da alma, mas também na dimensão integrante e constitutiva do homem em união com a alma. Aquilo que sou possui indissociavelmente uma dimensão corpórea. Não obstante, a discussão antropológica antes formulada no platonismo pela distinção corpo e alma, ganha espaço no augustinismo e a sua nova versão será formulada a partir da noção do homo totus, que consta de alma e carne, ou melhor, nas palavras do hiponense, de alma, espírito e carne (Cf. Ibdem,I, 17, 28). Tal versão antropológica pressupõe a totalidade do ser humano corpo/alma/espírito como elemento importante para a definição de sua essência, e não apenas a alma. Agostinho sustenta que a natureza íntegra do homem é espírito, alma e corpo, portanto, "quem pretende excluir o corpo da natureza humana pode causar um delírio para a filosofia" (Cf. De anima et eius origine, IV , 2,3).A partir desta definição de pessoa humana a dimensão carnal adquiriu uma pertinência antropológica, graças não somente ao pensamento de Agostinho, mas antes alguns autores da Patrística também refutaram vigorosamente o dualismo platônico ${ }^{4}$.

${ }^{4} \mathrm{O}$ termo latino "carnalis"aparece algumas vezes no De libero arbitrio no contexto aproximado a doutrina neoplatônica, cujo significado analógico pode ser dito como ente material, ou, aquelas ações apartadas 
De acordo com Margaret Miles, as doutrinas platônicas e, por conseguinte as estóicas, ainda permanecem fechadas em suas posições sobre a noção de homo totus, nelas não haviam espaço para uma filosofia do corpo, visto que essas doutrinasse ocuparam amplamente das disputas metafísicas e a filosofia ético-moralda natureza da alma (Cf. MILLES, 2009, p.02). Agostinho inaugura no pensamento tardo-antigo os alicerces de uma ontologia unitiva postulando conjecturas e especulações sobre a essência e existência. Agostinho em resposta ao platonismo escreve: uma alma, somente será alma do vivente se tiver um corpo que possa usá-lo, por sua vez, um corpo humano somente será corpo se estiver a serviço de uma alma.

Dito isto, é verdadeiro reconhecer que não pode existir pessoa humana alguma sem corpo e muito menos sem alma, portanto, escreve Agostinho, compete-nos agora investigar a natureza da alma e sua relação com o corpo,seu modo de agir em busca da felicidade (Cf. De beata vita, 2,7).

Em De civitate Dei observamos aclara distinção usual entre os termos, anima e animus. $\mathrm{O}$ primeiro deve ser usado para significar o princípio vital que anima e dá vida aos seres viventes; enquanto o segundo foi utilizado preferencialmente por Agostinho, para identificar na alma humana o princípio vital, caracterizado de substância racional, "summus gradus animae".

É certo que, no mesmo livro acerca dos deuses escolhidos, Varrão afirma que, no conjunto da natureza, a alma apresenta três graus. No primeiro, ela circula por todas as partes vivas do corpo, mas não tem sensibilidade, sendo apenas princípio de vida. No nosso corpo, diz ele, esta virtude impregna os nossos ossos, as nossas unhas, os nossos cabelos, como no mundo as árvores se alimentam, crescem e vivem à sua maneira sem gozarem de sensibilidade. No segundo grau, a alma possui sensibilidade, e essa virtude penetra nos nossos olhos, nos nossos ouvidos, nas nossas narinas, na nossa boca, no nosso tato. No terceiro grau, o mais elevado, a alma chama-se espírito e a inteligência domina aí: desta carecem todos os mortais exceto o homem. (De civitate Dei, VII, 23, 1)

A excelência da alma na antropologia agostiniana é constituída de mens, ratio, intellectus e spiritus. O termo spiritus possui dois sentidos diferentes no vocabulário de Agostinho; o primeiro deriva de Porfírio e está associado a imaginação ou memória sensivel que reproduz a imagem dos objetos apreendidos

\footnotetext{
de luz, ou do Uno: "Infelizes os que se afastam da tua luz e aderem docemente à sua própria obscuridade! De fato, como quem te volta às costas, fixam-se nas obras carnais como na sua própria sombra e, contudo, mesmo o que aí os deleita, ainda o recebem da irradiação da luz". Cf. De Libero arbitrio, II, 16,43; III, 5, $17 ;$ III, 9,27; III, 9,28; III, 10.29; III,18,52. Também a teologia do Verbo difusa por Tertuliano em que acentua o principal acontecimento do cristianismo, o Verbo de Deus se faz carne, trouxe para a condição humana carnal valor e significado.
} 
pelos sentidos, portanto, superior à vida (anima), mas inferior ao pensamento mens. (Cf. De Genesi ad litteram, XII, 24, 51) ${ }^{5} \mathrm{Na}$ esteira de Paulo de Tarso, Agostinho prefere usar o termo "spiritus", para designar a parte racional e espiritual da alma, aquela dimensão especifica do homem enquanto tal, distinguindo-o dos animais em geral. Em De Genesi ad Litteram, a noção de espírito refere-se à qualificação da alma e se encontra inferior à mente, nele estão representadas as semelhanças das realidades corporais (Cf. De Gen. ad litteram, XII, 9, 20). De acordo com Paula Silva, no interior do corpus agostiniano, nem sempre spiritus é empregado no sentido da atividade específica da mente, pois se toda mente é espírito, o contrário não ocorre necessariamente.

A mente apenas recolhe a atividade intelectual, enquanto queo spiritus também integra a dimensão da alma que recolhe as imagens corpóreas, cuja a atividade relaciona-se de algum modo com a visão sensível e com os corpos. Para o termo mens reservam-se as operações das suas faculdades próprias, a fim de nela se produzir a imagem de Deus, incorpórea e espiritual (Cf. SILVA e OLIVEIRA, 2000, p. 238).

Com efeito, pode-se falar de uma visão espiritual quando nos referimos àquela que se gera na alma através da memória sensível. Paula Silva observa no De ordine que aratio é o movimento pelo qual a mens passa de um conhecimento a outro, compondo-os ou fragmentando-os (Ibdem, Op. cit., p.239). "A ratio é o movimento da mens capaz de distinguir e estabelecer conexão entre as coisas que se conhecem"(Cf. De ordine, II, XI, 30). A mente, mesmo misturada do composto humano, a saber, corpo, vontade, paixões, mas iluminada pela luz natural, a luz da verdade, procura fazer a mediação entre a natureza humana e o divino, para ordenar a alma na sua relação com o corpo e através do comando da sabedoria reconduzir o homem à sua origem espiritual. A mens é a parte superior da alma racional «animus», é ela quem adere aos inteligíveis e a Deus, ela contém, naturalmente, duas outras faculdades, a ratio e a intelligentia, conforme atesta o próprio Agostinho em De civitate Dei; de fato, a mente se encontra unida, por natureza, à razão e à inteligência, embora as suas funções sejam diferentes no ato de conhecer a Verdade.

De fato, Deus não fala ao homem por uma criatura corpórea como se ferem os ouvidos do corpo fazendo vibrar o ar entre aquele que fala e aquele que ouve; [...] mas fala pela própria verdade se alguém está apto a ouvir pelo espírito e não pelo corpo. Fala deste modo à parte mais excelente do homem, superior a todos os elementos que constituem o homem e à qual só Deus é superior. (...), Mas como a própria parte mental,

5Toda referência feita a esta obra segue doravante a esta edição bilíngue francês/latim. Tradução nossa. 
sede natural da razão e da inteligência, está muito debilitada pelos vícios inveterados que a obscurecem, necessitava, antes de tudo, de ser purificada pela fé para aderir à luz imutável e dela gozar, ou mesmo para lhe suportar o esplendor, até que, renovada e curada dia a dia, se torne capaz duma tão grande felicidade (De Civitate Dei, XI, II).

A noção de corporeidade na antropologia agostiniana perpassa as dimensões corpo, alma, mente e espírito. Isto é, a noção de corpo como morada do espírito se dá na defesa de que pela carne também se cultivam as artes, os estudos, os encargos; a vida de uma pessoa é dada à carne, de modo que a morte e a vida pertencem à carne. Se todas as coisas são subordinadas à alma, mediante a carne, torna-se impossível ter outro instrumento, no qual haja movimento de vida, senão a própria carne.

A alma existe no corpo para dar forma ao ser, logo, a função do corpo é ser veículo-instrumento para as ações da alma. A ideia de vida interior com ressonâncias na vida exterior foi também um problema dispensado pelos platônicos, mas assumido com ênfase por Agostinho na sua tarefa de religar a alma a seu corpo, para que ela não tornasse o elo frágil ou inseguro no seu percurso para a Verdade. A união alma/corpo deve antes constituir um ponto de partida seguro e o corpo não deveria ser condenado por sentir as paixões que a alma lhe imprime, mas unido à alma tornaria um campo maior de força no combate às paixões que obstruem o conhecimento da Verdade.

Em De beata vita, Agostinho deduz que "da composição humana, de alma e corpo não se pode duvidar, mas resta saber se não existe outra coisa que seria para o homem um complemento de perfeição. De fato, para as duas formas desejou alimento, a natureza fixou aos corpos a dimensão à qual pode atingir, porém sequer atingiriam essa dimensão se lhes faltasse o alimento" (De beata vita, II, 7). E qual o alimento da alma? A resposta é sem dúvida a Sabedoria. Alimentados por esta Sabedoria, os homens sábios possuem o espírito mais pleno e mais livre. Já os espíritos desprovidos desse saber estão cheios de vícios e maldades. Do mesmo modo como o corpo, privado de alimento fica exposto a doenças e reações malignas decorrentes de sua inanição, assim o espírito ignorante fica impregnado de doenças (Cf. De beata vita, II, 7).

\section{Considerações finais}

Observamos que Agostinho dedica parte do De Genesis ad litteram ao estudo da alma e sua natureza, porque, segundo ele, o assunto não será de pouca importância para a filosofia. A sua tarefa consiste em combater as infundadas teses do maniqueísmo ao definir a natureza da alma como algo criado, obviamente não da mesma substância e essência do criador. 
A perspectiva conceitual do maniqueísmo é a da divergência entre duas substâncias, ou seja, a da existência de uma identidade da natureza humana dilacerada, tal concepção trouxe consequências para a compreensão antropológica da unidade do ser. Agostinho, em polêmica antimaniquéia acusa Mani pela ineficiência em compreender a doutrina da criação do homem e a natureza da alma, a partir dos seguintes aspectos: Em primeiro momento, os maniqueus investigam de forma inútil e infundada a ideia da criação do homem por meio do limo da terra, porque nela há insinuações de que faltava talvez uma matéria mais nobre e celeste que pudesse criar o homem e o inserir numa posição mais similar ao criador, para que não fosse criado da impureza terrena e assim tornasse de forma frágil e mortal. Por conseguinte, segundo Agostinho, se os maniqueus preferissem examinar os segredos das palavras, não as censurando e difamando-as, mas as investigando e respeitando-as, sem dúvida não seriam maniqueus (Cf. De Genesi contra Manicheos II. 2, 3), pois os maniqueus não entendem os vários significados que se encontram nas Sagradas Escrituras referentes à terra e à água (Cf. De Genesi contra Manicheos, II, 7, 8).

O limo, de acordo com Agostinho, não representa a fragilidade terrena da alma no corpo, mas a natureza carnal e suas vicissitudes, pois a alma foi criada de uma substância incorpórea, uniforme, não obstante, dotada de razão e mente e, portanto, não pode ser alterada em sua forma criada. Mas, o que levou à deformidade da alma? Agostinho diz que foram os vícios, pois a natureza da alma pode sofrer modificações pelos vícios das paixões, diferindo precisamente por isso, em essência e substância, da natureza do criador. A alma humana sofre mudanças pelo pecado considerando a grande variedade de sentimentos e afetos. A alma pertence deste modo, às realidades fugazes, devido a sua mutabilidade. E o corpo, somente depois do pecado passou a se corromper, por conseguinte, a tornar-se débil e sujeito à morte (De Genesi contra Manicheos, II, 7, 8; II, 7, 8). Sobre a criação humana Agostinho afirma que,

O homem foi feito de corpo e alma, e, portanto não é absurdo que tenha recebido o nome de limo devido a sua composição, pois, assim como a água se une, se aglutina e se junta à terra, quando dela se faz o limo pela mistura de ambos, assim a alma, comunicando a vida à matéria do corpo, conforma-se numa unidade harmônica e não permite que se corrompa e se destrua. (De Genesi contra Manicheos, II, 7, 8).

(...) "Contudo se a alma fosse um ser incomutável, não deveríamos de forma alguma procurar sua matéria; mas agora sua mutabilidade mostra claramente que se tornou disforme pelos vícios e embustes, e que se forma pelas virtudes e pala doutrina da verdade, mas em sua natureza pela qual é alma, assim como acontece com a carne que em sua natureza pela qual é carne se aformoseia com a saúde e se desfigura tanto 
pelas doenças como pelas chagas (De Genesi contra Manicheos, VII, 6, 9).

De acordo com a doutrina da criação, foi através do sopro divino que o criador insuflou no corpo humano um espírito de vida que se tornou uma alma viva. Se o homem era apenas um corpo animal, foi através desta ação que alma se uniu ao corpo dando-lhe vida. Contudo, a alma humana já estava nas entranhas do pensamento do criador. O sopro vivificante do criador dignificou a dimensão corpórea humana comunicando-lhe vida, saber e querer, momento em que o homem recebe do Verbo, forma e o começo de Ser.

Agostinho, jocoso, refuta as ideias levianas dos maniqueus sobre a dualidade da natureza humana:

Com efeito, se são tantas as naturezas contrárias quantas as vontades que a si mesmas resistem, já não serão duas as naturezas, mas várias. Se alguém ponderar se há de ir à assembleia deles, os Maniqueus, ou ao teatro, eles dizem: Eis aqui as duas naturezas, uma, a boa, que conduz para aqui, e outra, a má, que leva para acolá. Pois, donde vem essa hesitação das vontades que a si mesmas são contrárias? (Confissões.VIII, $10,23)$

Agostinho coloca a discussão a partir da radicalidade do conceito de criação, ao situar a natureza do bem ao nível de uma ontologia antignóstica e antimaniquéia, que parte do dinamismo ontológico já marcado pela sua doutrina da criação (CARVALHO, 1992, p. 31). Em resposta aos maniqueus, justifica, em Confissões, que o mal ontologicamente não existe, ou seja, não consiste em uma substância, por não ter parte na criação, porque tudo que Deus criou é louvável e belo. Tal argumento já havia sido fundamentado anteriormente, nas teses do De libero arbitrio, dado que em Confissões há apenas referência:

E, para ti, o mal não existe absolutamente, não apenas para ti, mas também não para toda a tua criação, porque não existe nada fora de ti que irrompa e corrompa a ordem que lhe impuseste. Mas, nas suas partes, algumas coisas são consideradas más para outras coisas, porque não estão em conformidade; mas essas mesmas coisas estão em conformidade com outras e são boas, e boas em si mesmas (Confissões, VII, 13,19).

A tese essencial da obra De Natura Boni contra Manichaeos presume que a natureza do corpo, enquanto circunscrição axiológica, equivale à natureza do espírito porque provém do criador de todas as coisas. Diz Agostinho: 


\begin{abstract}
Mas como ele é também justo, não podia igualar o que fez do nada àquilo que gerou. Porque todas as coisas boas, quer grandes ou pequenas, em qualquer dos seus graus, não podem existir senão por Deus e toda natureza enquanto natureza é um bem; nenhuma natureza pode existir senão pelo sumo e verdadeiro Deus. Logo, todo espírito é também mutável e todo o corpo provém de Deus. O espírito imutável é Deus; o espírito mutável é uma natureza criada, entretanto melhor que o corpo (De natura boni, I, 2, p.37).
\end{abstract}

Em De vera religione, Agostinho pretende formular uma preleção ao De Natura Boni quandoafirma que todos os bens criados são bons, pois a corrupção da alma não é pela sua natureza, mas somente contra a sua natureza e não é outra coisa senão o pecado e sob a pena do pecado compreende-se claramente que nenhuma natureza ou, melhor dizendo, nenhuma substância ou essência é coisa má (De uera religione,23, 44).

\title{
Referências
}

\section{Fontes primárias:}

AGOSTINHO DE HIPONA, Confissões. Tradução de Arnaldo do Espírito Santo, João Beato e Maria Cristina de Castro-Maia de Sousa Pimentel. Introdução de Manuel Barbosa da Costa Freitas. $2^{\mathrm{a}}$ edição, edição bilingue português/latim. Nacional-Casa da Moeda, Lisboa, 2004.

AGOSTINHO DE HIPONA, Diálogo sobre a felicidade. Edição bilingue português/latim.Tradução, introdução e notas de Mário Santiago de Carvalho, Ed. 70, Lisboa, 2010 ( $2^{\mathrm{a}}$ ed.).

AGOSTINHO DE HIPONA, Diálogo sobre o Livre Arbitrio. Tradução, introdução e notas de Paula Oliveira e Silva. Edição bilingue português/latim. Imprensa Nacional-Casa da Moeda, Lisboa, 2001.

AGOSTINHO DE HIPONA, Diálogo Sobre a ordem. Tradução, introdução e notas de Paula Oliveira e Silva. Imprensa Nacional-Casa da Moeda, Lisboa, 2000 . 
AGOSTINHO DE HIPONA, A natureza do bem. Introdução, tradução e notas de Mario A. Santiago de Carvalho, Instituto de filosofia, Porto, Portugal, 1992.

Agostinho DE HIPONA. A Cidade de Deus/ De Civitate Dei, XII, 27, p.1151. Tradução, Prefácio, Nota biográfica e transcrições, J. Dias Pereira, FCG, Lisboa, 1993, p. 1247.

SAN AGUSTIN, Del Génesis contra los maniqueos/De Genesi contra Manicheos,in: Obras completas de san Agustín. Vol. XV. Trad. introd. y notas de Balbino Martín. Madrid, BAC, 1957, p. 428.

SAINT AUGUSTIN, La Genèse au sens littéral/De Genesi ad litteram. CSEL28 (J. ZYCHA, 1972)]. Traduction introduction et notes par P. Agaësse et A. Solignac. DESCLÉE DE BROUWER, Paris, 1972, 415p.

AGOSTINHO DE HIPONA, De beata vita, 2,7, p.124/Diálogo sobre a felicidade. Tradução, introdução e notas de Mário Santiago de Carvalho, $2^{a}$ ed., Edições 70, Lisboa, 2010.

AGOSTINHO DE HIPONA, A verdadeira religião/De vera religione. Tradução bilíngue português/latim, Introdução e notas de Paula Oliveira e Silva e Manuel Ramos, Porto Portugal, Edições afrontamento, 2012, 200p.

SAN AGUSTIN, Del alma y su origen/De Anima et eius origine, libri quatuor, (PL 44) I, 17, 28. Versión, introducciones y notas, Victorino Capanaga, O.S.A. et al., Madrid: La Editorial Catolica/BAC, 1963, p. 329.

SAN AGUSTIN, De la cuantidad del alma/De Quantitate animae in: Obras completas de san Agustin. $3^{\text {a }}$ ed. Bilingue latim/espanhol. versión, introducciones y notas Trad. introd. y notas de Victorino Capánaga, et al.Madrid: La Editorial Catolica/BAC, 1963, 448 p.

\section{Estudos:}

BARDY, G., Saint Augustin, l'homme et l'oeuvre.Études Augustiniennes. Paris, Desclée de Brouwer, 1948. IX 557 p.

BEIERWALTES, Werner. Agostino e il Neoplatonismo cristano. Prefazione e Introduzione di Giovanni Reale, traduzione di Giuseppe Girgenti e Alessandro Trotta. Milano, Vita e Pensiero, 1995. 
BENOIT, Hector (org). Estudo sobre o diálogo Filebo de Platão, a procura da Eudaimonia. Ijuí: Ed. Unijuí, 2007.

BERMONT, E., Le cogito dans la pensée de Saint Augustin. Vrin, Paris 2001.

BROWN, Peter. Santo Agostinho, uma biografia. Tradução de Vera Ribeiro, $5^{a}$ ed., Rio de Janeiro: 2008.

GRAVER, Margaret. Cicero on the emotions. Tusculan Disputations 3 and 4. London, The University of Chicago, 2002.

MILLES. Margaret R. Augustine, on the Body. Eugene, Oregon, WIPF AND STOCK, 2009.

PLATON, Pbilèbe, in Oewrres Complètes, t. IX, IIème Partie, (texte établi et traduit par Auguste Diès), Paris, Les Belles Lettres, 1993.

MECONI, David Vincent e Eleonore STUMP (org). Agostinho. Tradução Jaime Clasen, São Paulo, Ideias e Letras, 2016.

PLOTIN. Ennéades III. Tradução Émile Bréhier, Paris: Les Belles Lettres, 1925. SILVA e OLIVEIRA, Paula. Ordem e mediação, a ontologia relacional de Agostinho de Hipona. Porto Alegre RS, Letra e Vida, 2012 